\title{
BAGI HASIL PERTAMBANGAN MINYAK BUMI ANTARA PEMERINTAH PUSAT DAN PEMERINTAH DAERAH
}

\author{
Eko Nuriyatman \\ Fakultas Hukum Universitas Adiwangsa Jambi \\ Jalan Sersan Muslim RT.24 Kebun Kopi, Kel Thehok, Kec.Jambi Selatan \\ Ekonuriyatman90@gmail.com
}

\begin{abstract}
Writing this scientific article is a research with normative (doctrinal) research method which aims to find out the legal review of the regulation of revenue sharing of petroleum mining between the central government and regional governments. This study uses an analysis of secondary data that the authors obtained from various literatures using the law approach, conceptual approach and case approach that occurs in everyday life regarding petroleum. The difference in the mechanism of distribution of funds and profit sharing between the central government and local governments results in imbalances in economic growth between all regions in Indonesia. The results of the research and analysis carried out by the authors indicate that the regulation of mintak mining revenue sharing funds between the central government and local governments through general allocation funds, special allocation funds and revenue sharing funds is in line with the objectives of regional autonomy, but lack of attention from the central the regions that have the highest natural resource income and lack of attention to development will lead to inequality between revenue sharing funds from the central government and regional governments. Supposedly with equal distribution between central government and regional government through policies in the form of natural resource priorities, it will create a main goal of the law, namely legal certainty, justice for some people and the last is to provide benefits to the community.
\end{abstract}

Keywords: Profit Sharing, Petroleum Mining

\begin{abstract}
Abstrak
Penulisan artikel ilmiah ini merupakan penelitian dengan metode penelitian normatif (doktrinal) yang bertujuan untuk mengetahui tinjauan hukum terhadap pengaturan dana bagi hasil pertambangan minyak bumi antara pemerintah pusat dan pemerintah daaerah. Penelitian ini menggunakan analisis pada data sekunder yang penulis dapat dari berbagai literatur dengan menggunakan pendekatan undang-undang, pendekatan konseptual dan pendekatan kasus yang terjadi dalam kehidupan sehari-hari mengenai minyak bumi. Perbedaan mekanisme pembagian dana dan bagi hasil antara pemerintah pusat dan pemerintah daerah berakibat ketimpangan pertumbuhan ekonomi antara semua daerah yang ada di Indonesia. Hasil dari penelitain dan analisis yang dilakukan oleh penulis menunjukkan bahwa pengaturan dana bagi hasil pertambangan mintak bumi antara pemerintah pusat dan pemerintah daerah melalui dana alokasi umum, dana alokasi khusus dan dana bagi hasil sudah sesuai dengan tujuan dari otonomi daerah, namun kurangnya perhatian dari pemerintah pusat terhadap daerah-daerah yang memiliki penghasilan sumber daya alam tertinggi serta kurangnya perhatian terhadap pembangunan akan mengakibatkan terjadinya ketimpangan antara dana bagi hasil pemerintah pusat dan pemerintah daerah. Seharusnya dengan adanya pemerataan antara pemerinta pusat dan pemerintah daerah melalui kebijakan berupa prioritas sumber daya alam akan menimbulkan suatu tujuan utama dari hukum, yaitu kepastian hukum, keadilan bagi sebagian masyarakat dan yang terakhir adalah akan memberikan manfaat bagi masyarakat.
\end{abstract}

Kata Kunci: Bagi Hasil, Pertambangan Minyak Bumi 


\section{Pendahuluan}

Pemerintahan daerah merupakan salah satu alat dalam sistem peyelenggaraan pemerintahan, pemerintahan daerah ini merujuk pada otoritas administrasi di suatu daerah yang lebih kecil dari sebuah negara dimana Negara Indonesia merupakan sebuah negara yang wilayahnya terbagi atas daerah-daerah provinsi, daerah provinsi ini dibagi lagi atas daerah kabupaten dan daerah kota. Setiap daerah provinsi, daerah kabupaten dan daerah kota mempunyai pemerintahan daerah yang diatur dengan undang-undang. Undang-Undang Republik Indonesia Nomor 23 Tahun 2014 tentang Pemerintahan Daerah, mendefenisikan bahwa pemerintahan daerah merupakan kepala daerah sebagai unsur peyelenggaraan pemerintahan daerah yang memimpin pelaksanaan urusan pemerintahan yang menjadi kewenangan daerah otonom.

The Liang Gie, mendefenisikan bahwa pemerintahan daerah adalah satuan-satuan organisasi pemerintah yang berwenang untuk menyelenggarakan segenap kepentingan setempat dari kelompok yang mendiami suatu wilayah yang dipimpin oleh kepela pemerintahan daerah. ${ }^{1}$ Pada awalnya lahirnya pemerintahan adalah untuk menjaga suatu sistem ketertiban di dalam masyarakat, sehingga masyarakat tersebut bisa menyeleggaraka kehidupan secara wajar. Pemerintah pada era modern ini tidaklah ada untuk melayani diri sendiri, namun untuk melayani masyarakat serta menciptakan kondisi yang memungkinkan setiap anggota untuk dapat mengembangkan diri dan kreatifitas demi mencapai kemajuan bersama.
Pasal 1 angka 2 Undang-Undang Republik Indonesia Nomor 23 Tahun 2014 menyebutkan bahwa Pemerintahan Daerah adalah penyelenggara urusan pemerintah oleh Pemerintah Daerah dan Dewan Perwakilan Rakyat Daerah menurut asas otonomi dan tugas pembantuan dengan prinsip otonomi seluas-luasnya dalam sistem dan prinsip Negara Kesatuan Republik Indonesia Tahun 1945. Kaufman berpendapat bahwa tugas pemerintah adalah untuk melayani dan mengatur masyarakat, lebih lanjut bahwa tugas pelayanan lebih menekankan upaya mendahulukan kepentingan umum, mempermudah urusan publik dan memberikan kepuasan publik, sedangkan tugas mengatur lebih menekankan kekuasaan (power) yang melekat pada posisi jabatan birokrasi. ${ }^{2}$ Dengan begitu luas dan kompleksnya tugas dan fungsi pemerintahan menyebabkan pemerintah harus memikul tanggungjawab yang sangat besar, untuk mengemban tugas yang sangat besar itu selain diperlukan sumber daya manusia yang baik juga diperlukan institusi yang kuat dengan aparatur yang memiliki prilaku yang sesuai dengan nilai dan norma yang berlaku di dalam masyarakat dan pemerintah.

$$
\text { Undang-Undang Dasar Negara Republik }
$$
Indonesia 1945 telah mengamanatkan diselenggarakannya otonomi seluas-luasnya dalam kerangka Negara Kesatuan Republik Indonesia, untuk itu perlu adanya pemberlakuan secara adil dan selaras mengenai hubungan keuangan, pelayanan umum, pemanfaatan sumber daya alam dan sumber daya lainnya antara pemerintah pusat dan pemerintah daerah. Ketentuan tersebut dibuktikan dengan Pasal 18A Undang-Undang Dasar Negara Republik Indonesia 1945, yaitu sebagai berikut:

\footnotetext{
1 Josep Riwu Kahu. Analisis Hubungan Pemerintah Pusat dan Daerah di Indonesia. Yogyakarta: Cetakan Ketiga. Center for Political and Government (Polgov) FISIPOL UGM, 2012, hlm. 174.

2 Kaufman. Tugas dan Tanggungjawab Pemerintah. Jakarta: Refika Aditama, 2011, hlm. 253.
} 
1. Hubungan wewenang antara pemerintah pusat dan pemerintah daerah provinsi, kabupaten dan kota, atau antara provinsi dan kabupaten dan kota, diatur dengan undang-undang dengan memperhatikan kekhususan dan keragaman daerah.

2. Hubungan keuangan, pelayanan umum, pemanfaatan sumber daya lainnya antara pemerintah pusat dan pemerintah daerah diatur dan dilaksanakan secara adil dan selaras berdasarkan undang-undang.

Fenomena yang harus diwaspadai atas berbagai persoalan dan ekses tersebut dapat dirangkum dalam suatu prespektif persoalan yaitu ketimpangan antara hubungan pusat dan daerah khususnya lagi mengenai perimbangan keuangan yang menyangkut pembagian hasil pemanfaatan sumber daya alam yang ada di daerah. Sarundajang berpendapat bahwa, ada dua pandangan tentang peranan yang seharusnya dilakukan oleh pemerintah daerah dalam hubungannya dengan keuangan pemeritah pusat dan pemerintah daerah. Pertama, yaitu menekankan peranan pemerintah daerah sebagai ungkapan dari kemauan dan identitas masyarakat setempat. Kedua, pemerintah daerah pada dasarnya merupakan lembaga yang menyelenggarakan layanan-layanan tertentu untuk daerah, dan memberikan layanan yang semata-mata bermanfaat untuk daerah. ${ }^{3}$

Guna melaksanakan kewajiban dalam malaksanakan otonominya dan sebagai bagian dari pendistribusian penyelenggaraan kekuasaan pemerintahan negara, maka daerah-daerah memerlukan pembiyaan yang memadai dan cukup. Namun harus disadari bahwa keterbatasan sumber daya yang dapat diandalkan oleh daerah guna menghasilkan pendapatan asli daerah, maka pelaksanaan otonomi daerah tersebut tidaklah berimplikasi kepada keharusan bagi setiap daerah untuk menutupi segala pembiayaan jalanya pemerintahan daerah itu secara penuh harus dibiayai oleh sumber pendapatan asli daerahnya. Dalam keadaan seperti ini, pemerintah pusat memiliki kewajiban untuk memberikan transfer sumber-sumber pembiayaan lainya kepada pemerintah daerah yang menjadi suatu keharusan.

Dalam konteks inilah kebijakan desentralisasi fiskal merupakan solusi bagi pemerintah pusat dan daerah untuk sama-sama memanfaatkan sumber keuangan yang dapat digali dalam batas-batas wilayah Negara Indonesia untuk dimanfaatkan dan dibagi secara proporsional dan rasional di antara kedua tingkatan pemerintah tersebut. ${ }^{4}$ Hubungan keuangan antara pemerintah pusat dan pemerintah daerah dapat diartikan sebagai suatu sistem yang mengatur bagaimana caranya sejumlah dana dibagi di antara berbagai tingkat pemerintah, serta bagaimana caranya mencari sumber-sumber pembiayaan daerah untuk menunjang kegiatan sektor publiknya.

Hubungan keuangan antara pemerintah pusat dan daerah diartikan sebagai suatu sistem yang mengatur bagaimana caranya sejumlah dana dibagi di antara berbagai tingkat pemerintah, serta bagaimana caranya mencari sumber-sumber pembiayaan daerah untuk menunjang kegiatankegiatan sektor publiknya. ${ }^{5}$ Alokasi anggaran dari pusat ke daerah atau perimbangan keuangan pusat dan daerah sering disebut juga dengan transfer pemerintah. Adanya sistem bagi hasil atau

3 Ahmad Yani. Hubungan Keuangan Antara Pemerintah Pusat dan Daerah di Indonesia. Jakarta: PT.Raja Grafindo Persada, 2009, hlm. 16.

4 Bambang. "Desentralisasi Fiskal Menurut Studi Bank Dunia." Jurnal Keuangan, Oktober 2010: Vol. IV, No.4, hlm. 5.

5 Mukhtie Fadjar Dkk. "Konstitusi Demokrasi: Sebuah Diskursus Tentang Pemilu, Otonomi Daerah dan Mahkamah Konstitusi." Jurnal Konstitusi, Januari 2011: Vol.VII, No.7, hlm. 4. 
perimbangan ini, berdasarkan alasan tersebut maka perlu dialokasikan dana untuk pembangunan di tingkta daerah, baik berupa alokasi umum (DAU), dana alokasi khusus (DAK) maupun dengan sistem bagi hasil.

DAU yaitu dana yang berasal dari Anggaran Pendapatan dan Belanja Negara (APBN) yang dialokasikan dengan tujuan pemerataan kemampuan keuangan antara daerah untuk pembiayaan kebutuhan pengeluaran dalam rangka pelaksanaan desentralisasi. Pasal 7 UndangUndang Republik Indonesia Nomor 33 Tahun 2004 menyebutkan bahwa besarnya DAU ditetapkan sekurang-kurangnya 25 persen dari penerimaan dalam negeri yang ditetapkan dalam APBN, pembagian dana untuk daerah provinsi dan untuk daerah kabupaten/kota ditetapkan masing-masing 10 persen dan 90 persen dari DAU. Sedangkan DAK dalam Undang-Undang Republik Indonesia Nomor 33 Tahun 2004 adalah dana yang berasal dari APBN yang dialokasikan kepada daerah untuk membantu pembiayaan kebutuhan khusus, termasuklah yang berasal dari dana reboisasi yang mana penerimaan negara berasal dari reboisasi sebesar 40 persen disediakan kepada daerah penghasil sebagai DAK.

Berkaitan dengan otonomi daerah yang "memberikan kewenangan yang luas, nyata dan bertanggung jawab kepada daerah secara proporsional yang diwujudkan dengan pengaturan pembagian dan pemanfaatan sumber daya nasional serta perimbangan keuangan pemerintah pusat dan daerah dan ini dilaksanakan sesuai dengan prinsip demokrasi, peran serta masyarakat, pemerintah dan keadilan serta potensi dan keanekaragaman daerah yang dilaksanakan dalam kerangka NKRI. ${ }^{6}$ Transfer dana dari pusat ke daerah seyogyanya memperhatikan beberapa hal penting agar kebijakan ini tepat guna dan dapat bermanfaat bagi pemerintah pusat dan khususnya bagi daerah itu sendiri. Beberapa hal yang paling penting diperhatikan adalah penerimaan yang memadai bagi daerah dalam rangka menjalankan fungsi pemerintahannya. Menurut Elmi secara umum tujuan pemerintah pusat melakukan transfer dana kepada pemerintah daerah adalah:

1. Sebagai tindakan nyata untuk mengurangi ketimpangan pembagian keuangan nasional baik vertikal maupun horizontal.

2. Suatu upaya untuk meningkatkan efesiensi pengeluaran pemerintah dengan menyerahkan sebagian kewenangan di bidang pengelolaan keuangan negara dan agar manfaat yang dihasilkan dapat dinikmati oleh rakyat di daerah yang bersangkutan. $^{7}$

Bantuan dana dari pemerintah pusat tersebut hanyalah sebagai bentuk rangsangan bagi daerah agar lebih meningkatkan sumber penerimaan pendapatan asli daerahnya, yang merupakan bagian penting dari sumber penerimaan daerah dan bukan menjadikannya sebagai prioritas utama dalam penerimaan daerah. Pasal 14 huruf e UndangUndang Republik Indonesia Nomor 33 Tahun 2004 Tentang Perimbangan Keuangan Pusat dan Daerah yang mana mengenai pertambangan minyak lebih sedikit yang dikembalikan kepada daerah bersangkutan, yaitu hanya 15,5 persen saja, sedangkan sisanya masuk dalam kas pemerintah pusat. Pada huruf $f$ yang mengatur bagi hasil pertambangan gas bumi agak sedikit menguntung-

6 Rustian Kamaluddin. "Perimbangan Keuangan Pusat dan Daerah Dalam Rangka Otonomi Daerah." Jurnal Hukum Inovatif, Juli 2009: Vol.3, No.Vl, hIm. 2.

7 Helmi. “Kebijakan Pemerintah Daerah Antara Pemerintah Pusat.” Jurnal Ilmu Hukum, Agustus 2011: Vol.II, No.1, hlm 3. 
kan daerah, yakni sebanyak 30,5 persen untuk daerah penghasilnya dan yang paling menguntungkan adalah daerah yang menghasilkan panas bumi. Daerah penghasil panas bumi dapat menikmati hasil panas buminya sebanyak 80 persen yang diatur dalam Pasal 14 huruf $g$ dalam undangundang tersebut.

Perimbangan keuangan antara pemerintah pusat dan pemerintah daerah terkait hasil tambang yang diatur dalam Undang-Undang Republik Indonesia Nomor 04 Tahun 2009 Tentang Pertambangan Mineral dan Batubara, relatif memberikan angin segar bagi daerah penghasil karena pada Pasal 129 ayat (1) memberikan 6 (enam) persen dari keuntungan bersih kepada daerah dan 4 (empat) persen untuk pemerintah pusat. Pada sektor kehutanan pada huruf a dalam Undang-Undang Republik Indonesia Nomor 33 Tahun 2004 memberikan angin segar pula untuk daerah, yaitu dengan pembagian 80 persen untuk daerah bagi penerima iuran Hak Pengusahaan Hutan (IHPH) dan Provinsi Sumber Daya Hutan (PSDH). Pemberian sumber-sumber keuangan, pengalokasian dana perimbangan dan pemberian pinjaman dan/atau hibah sedangkan hubungan antar pemerintah daerah dalam bidang keuangan meliputi bagi hasil pajak dan non pajak antara pemerintah daerah profinsi dan pemerintah kabupaten/kota. ${ }^{8}$

Adanya perbedaan bagi hasil antara sumber penghasilan yang satu dengan sumber penghasilan yang lain akan berakibat ketimpangan penerimaan daerah dan bagi daerah yang mempunyai sumber daya alam seperti pertambangan akan merasa tidak adil. Pasal 1 Angka 49 Undang-Undang Republik Indonesia
Nomor 2 Tahun 2015 Tentang Penetapan Peraturan Pemerintah Pengganti Undang-Undang Nomor 2 Tahun 2014 Tentang Perubahan Atas UndangUndang Republik Indonesia Nomor 23 Tahun 2014 Tentang Pemerintahan Daerah, menyebutkan bahwa Dana Bagi Hasil adalah dana yang bersumber dari pendapatan tertentu Anggaran Pendapatan Belanja Negara yang dialokasikan kepada daerah penghasil berdasarkan angka persentase tertentu dengan tujuan mengurangi ketimpangan kemampuan keuangan antara pemerintah pusat dan pemerintah daerah.

Berdasarkan kedua undang-undang tersebut terdapat beberapa permasalahan pembagian hasil tambang, khususnya tambang minyak bumi yang hingga menjadi kewenangan daerah untuk kemakmuran daerah tersebut. Namun terdapat kekaburan norma antara Undang-Undang Republik Indonesia Nomor 2 Tahun 2015 dengan Pasal 14 huruf e Undang-Undang Republik Indonesia Nomor 33 Tahun 2004. Selain itu, merujuk pada Undang-Undang Republik Indonesia Nomor 2 Tahun 2015 dengan Pasal 14 Undang-Undang Nomor 33 Tahun 2004 maka timbul permasalahan apakah dana bagi hasil yang persentase alokasi dananya mampu mengurangi ketimpangan kemampuan keuangan pemerintah pusat dan pemerintah daerah mengigat bahwa alokasi dana terhadap pemerintah pusat yang cukup besar sebesar 84,5 persen, sehingga tampak jelas kekaburan norma di dalamnya.

\section{Tinjauan Pustaka}

Dana perimbangan merupakan sumber pendapatan daerah yang berasal dari Anggaran

8 Siswanto Sunarno. Hukum Pemerintahan Daerah di Indonesia. Jakarta: Sinar Grafika, 2009, hlm. 36. 
Pendapatn dan Belanja Daerah (APBD) untuk mendukung penyelenggaraan pemerintahan daerah dalam hal mencapai tujuan pemerintahan yang otonomi kepada daerah. Namun selama ini sumber dana pembangunan daerah di Indonesia mencerminkan ketergantungan terhadap sumbangan dan bantuan dari pemerintah pusat. Padahal menurut pendapat penulis bantuan dari pemerintah pusat tersebut hanyalah untuk rangsangan bagi daerah agar lebih meningkatkan sumber penerimaan pendapatan asli daerahnya.

Pembagian dana perimbangan terbagi menjadi tiga hal, pertama, Bagian Daerah yaitu Bagi Hasil Pajak dan Bagi Hasil Bukan Pajak sumbersumber penerimaan perpajakan yang dibagihasilkan meliputi Pajak Penghasilan (PPh) Pasal 21 dan Pasal 25/29 orang pribadi, Pajak Bumi dan Bangunan (PBB), serta bagian perolehan Hak Atas Tanah dan Bangunan (BPHTB). Sementara itu sumber-sumber penerimaan SDA yang dibagi hasilkan adalah minyak bumi, gas alam, pertambangan umum, kehutanan dan perikanan. Berdasarkan Peraturan Pemerintah Republik Indonesia Nomor 115 Tahun 2000 Tentang Pembagian Hasil Penerimaan Pajak Penghasilan Orang Pribadi Dalam Negeri dan Pajak Penghasilan Pasal 21 Antara Pemerintah Pusat dan Pemerintah Daerah, bagian daerah dari PPh, baik PPh 21 maupun PPh Pasal 25/29 orang pribadi ditetapkan masing-masing 20 persen dari penerimaannya.

Kedua, yaitu Dana Alokasi Umum (DAU) yang mana menurut Undang-Undang Republik Indonesia Nomor 33 Tahun 2004 yang dimaksud dengan DAU yaitu dana yang berasal dari APBD yang dialokasikan dengan tujuan pemerataan kemampuan keuangan antara daerah dalam era desentralisasi. Pada Pasal 7 Undang-Undang Republik Indonesia Nomor 33 Tahun 2004 besaran DAU ditetapkan sekurang-kurangnya 25 persen dari pemerintah dalam negeri yang ditetapkan dalam APBN, sedangkan DAU untuk pemerintah provinsi dan pemerintah kabupaten/kota ditetapkan masingmasing 10 persen dan 90 persen dari DAU.

Ketiga, Dana Alokasi Khsusu (DAK) menurut Undang-Undang Republik Indonesia Nomor 33 Tahun 2004, yaitu dana yang berasal dari APBN yang dialokasikan kepada daerah untuk membantu membiayai kebutuhan khusus, termasuklah yang berasal dari dana reboisasi sebesar 40persen disediakan kepada daerah penghasil sebagai DAK adapun kebutuhan khusus yang dimaksud, yaitu kebutuhan yang tidak dapat diperkirkan dengan menggunakan rumus alokasi umum, dan/atau kebutuhan yang merupakan komitmen atau prioritas nasional.

Selain Dana Perimbangan terdapat pula Pendapatan Asli Daerah (PAD). PAD adalah suatu pendapatan yang menunjukkan kemampuan suatu daerah untuk menghimpun sumber-sumber dana untuk membiayai kegiatan daerah. ${ }^{9}$ Hak tersebut sebagaimana terdapat dalam Pasal 6 UndangUndang Republik Indonesia Nomor 23 Tahun 2014.

\section{Metode Penelitian}

Suatu penelitian hukum erat kaitanya terhadap konsep hukum yang digunakan bahwa menurut Soetondyo Wigyosoebroto terhadap lima konsep hukum, konsep-konsep hukum tersebut sebagai berikut:

\footnotetext{
9 Josep Riwu Kaho. Op. Cit. hlm. 5.
} 
1. Hukum adalah asas kebenaran dan keadilan yang berlaku kodrati dan berlaku universal;

2. Hukum adalah norma-norma positif di dalam sistem perundang-undangan;

3. Hukum adalah apa yang diputuskan oleh hakim (in concreto) dan tersistemasisasi sebagai judge made law;

4. Hukum adalah pola-pola perilaku social yang terlembaga eksis sebagai variable sosial yang empirik; dan

5. Hukum adalah manifestasi makna-makna simbolik para perilaku sosial sebagai tampak dalam interaksi antar mereka. ${ }^{10}$

Pada konsep hukum pertama, kedua dan ketiga sering disebut dengan konsep hukum doktrinal (normatif), konsep hukum ini merupakan suatu norma, baik yang diindentikan dengan keadilan yang harus diterapkan (ius constituedum) atau norma yang dibentuk dalam suatu perintah atau undang-undang (ius constituetum) agar terjamin kepastian hukumnya. Selanjutnya ada pula normanorma yang terdapat dalam putusan-putusan yang merupakan produk hakim (judgements), sehingga penelitian-penelitian yang berdasarkan normanorma hukum tersebut sebagai penelitian doktrinal. Selanjutnya pada konsep keempat dan kelima adalah konsep hukum normologi. Penelitian hukum pada karya ilmiah ini adalah menggunakan penelitian hukum doktrinal.

\section{Pembahasan}

Berdasarkan latar belakang masalah yang telah penulis paparkan di atas maka dapat dibahas bahwa, semenjak otonomi daerah digulirkan ada kebijakan pemerintah pusat untuk memberi sumber keuangan yang semula cenderung dikuasai sepenuhnya oleh pemerintah pusat dikembalikan kepada pemerintah daerah penghasil. Dikatakan "sebagian" karena dengan konsep NKRI maka daerah bukan penghasil dalam satu provinsi otomatis juga akan menerima sebagian dari sumber daya alam (SDA) yang diperoleh dari suatu daerah. Dengan 6:3 dari 15 yakni dari bagian daerah 15 persen dibagi untuk daerah penghasilan 6 persen, bukan daerah penghasil dalam provinsi 6 persen dan propinsi 3 persen. Sedangkan 85 persen menjadi bagian pemerintah pusat, di mana dalam perkembangan diberikan lagi 0,5 persen kepada daerah untuk mendukung program pendidikan dasar dengan alokasi 0,2 persen untuk daerah penghasil, 0,2 persen untuk seluruh derah bukan penghasil dalam provinsi dan 0,1 persen untuk provinsi. ${ }^{11}$

Semenjak berlakunya Undang-Undang Republik Indonesia Nomor 33 Tahun 2004 muncul berbagai proteksi ketidaksetujuan atas isi undangundang tersebut, protes pertama diajukan oleh daerah-daerah yang kaya akan SDA seperti Nanggroe Aceh Darusallam (NAD), Riau dan Kalimantan Timur (Kaltim). Jika dilihat dari komposisi penerimaan dari ketiga daerah tersebut, dana 50 persen merupakan pendapatan untuk daerah.

Pemerintah daerah menyelenggarakan otonomi daerah untuk mengatur dan mengurus sendiri urusan pemerintahan berdasarkan asas otonomi dan tugas pembantuan. ${ }^{11}$ Sejalan dengan otonomi yang seluas-luasnya dilaksanakan pula prinsip otonomi yang nyata dan bertanggung jawab,

\footnotetext{
10 Setiono. Pemahaman Terhadap Metodologi Penelitian Hukum. Surakarta: Program Studi IImu Hukum Pasca Sarjana Universitas Sebelas Maret (UNS), 2010, hlm. 20.

11 Syaiful Bakhri. Migas Untuk Rakyat Pergulatan Pemikiran Dalam Peradilan Mahkamah Konstitusi. Jakarta: Grafindo Khazanah IImu, 2013, hIm. 232.

12 Amran Muslimin. Aspek-Aspek Hukum Otonomi Daerah. Bandung: Alumni, 2010, hlm. 39.
} 
dengan demikian isi dan jenis otonomi bagi setiap daerah tidak selalu sama dengan daerah lainnya. Seiring dengan hal tersebut maka penyelenggaraan otonomi daerah harus selalu berorientasi pada peningkatan kesejahteraan masyarakat dengan selalu memperhatikan kepentingan dan apresiasi yang tumbuh dalam masyarakat.

Berdasarkan kententuan Undang-Undang Republik Indonesia Nomor 33 Tahun 2004 pengaturan sumber dana bagi daerah terdiri dari pendapatan asli daerah (PAD), dana perimbangan, dan pinjaman daerah, dekonsentrasi serta tugas pembantuan. Dengan mengorelasikan antara Undang-Undang Republik Indonesia Nomor 33 Tahun 2004 dan Undang-Undang Republik Indonesia Nomor 23 Tahun 2014 terlihat bahwa kewenangan/urusan yang dimiliki oleh pemerintah daerah yang begitu besar dan penting tidak sinergi dan tidak konsisten dengan pendanaan yang diberikan untuk menjalankan/menyelenggarakan urusan/kewenangan tersebut.

Wahyudi Kumorotomo menyatakan bahwa rumus-rumus perimbangan keuangan itu dibuat tanpa keterangan yang jelas mengenai dasar-dasar rasionalitasnya. ${ }^{13}$ Dari semua dokumen parlemen yang ada tidak dapat ditemukan dasar dari dibuatnya pembagian pendapatan atau angka persentasenya. Selanjutnya hubungan fiskal antar jenjang pemerintahan hanya terdapat perubahan-perubahan kecil. Namun secara keseluruhan ketentuan mengenai pembagian pajak antar jenjang pemerintahan masih tetap sama dengan undangundang sebelumnya. Kebijakan desentralisasi fiskal akan tetap dipengaruhi oleh negoisasi-negoisasi politik di antara jenjang pemerintah yang berbeda.
Pasal 14 huruf e dan huruf $f$ UndangUndang Republik Indonesia Nomor 33 Tahun 2004 tidak memiliki ratio legis (alasan hukum), sehingga mengakibatkan adanya ketidakpastian hukum yang adil. Hal ini jelas melanggar ketentuan Pasal 28D ayat (1) Undang-Undang Dasar Negara Republik Indonesia Tahun 1945. Pasal 14 huruf e dan $\mathrm{f}$ tersebut jelas telah bertentangan dengan Pasal 1 ayat (1) dan Pasal 33 ayat (1), ayat (3) dan ayat (4) Undang-Undang Dasar Negara Republik Indonesia Tahun 1945. Berhubungan dengan persentase dana bagi hasil minyak bumi dan gas bumi yang diperoleh oleh NAD dan Papua mencapai 70persen. Untuk NAD hal tersebut berdasarkan Pasal 181 ayat (1) huruf $b$ angka 5 dan angka 6 serta ayat (3) UndangUndang Republik Indonesia Nomor 11 Tahun 2006 Pemerintahan Aceh yang menyatakan: (1) Dana perimbangan sebagaimana dimaksud dalam Pasal 179 ayat (2) huruf b terdiri atas: b. Dana Bagi Hasil yang bersumber dari hidrokarbon dan sumber daya alam lain, yaitu: 5) bagian dari pertambangan minyak sebesar 15persen; dan 6) bagian dari pertambangan gas bumi sebesar 30persen. (3) Selain Dana Bagi Hasil sebagaimana dimaksud pada ayat (1) huruf $b$, Pemerintah Aceh mendapat tambahan Dana Bagi Hasil minyak dan gas bumi yang merupakan bagian dari penerimaan Pemerintah Aceh, yaitu: a. bagian dari pertambangan minyak sebesar 55 persen; dan b. bagian dari pertambangan gas bumi sebesar 40persen. Berdasarkan dua ketentuan tersebut dapat dilihat dana bagi hasil yang diterima oleh Aceh untuk Migas adalah minyak bumi sebesar 70 persen dan gas sebesar 70 persen.

Pembagian bagi hasil Migas untuk Papua berdasarkan pada Pasal 34 Undang-Undang

13 Wahyudi Kumorotomo. Desentralisasi Fiskal, Politik dan Perubahan Kebijakan 1974-2004. Jakarta: Kencana Prenanda Group, 2008, hlm. 259. 
Republik Imdonesia Nomor 21 Tahun 2001 Tentang Otonomi Khusus Provinsi Papua mengatur pembagian hasil minyak bumi dan gas alam, di mana Dana Pertimbangan bagian Provinsi Papua, Kabupaten/Kota dalam rangka Otonomi Khusus. Bagi hasil SDA Pertambangan minyak bumi adalah sebesar 70 persen dan pertambangan gas alam sebesar 70 persen. Penerimaan dalam rangka Otonomi Khusus berlaku selama 25 tahun. Dan mulai tahun ke-26, penerimaan dalam rangka Otonomi Khusus menjadi 50 persen untuk pertambangan minyak bumi dan sebesar 50 persen untuk pertambangan gas alam.

Untuk daerah lain selain Aceh dan Papua pembagian dana bagi hasil minyak bumi dan gas tersebut berlaku ketentuan Pasal 14 huruf e dan huruf $f$ Undang-Undang Perimbangan Keuangan Pusat dan Daerah. Di mana presentase penerimaan pertambangan minyak bumi yang dihasilkan dibagi dengan imbangan 84,5 persen untuk Pemerintah dan 15,5 persen untuk daerah dan presentase penerimaan pertambangan gas bumi dibagi dengan imbangan 69,5 persen untuk Pemerintah dan 30,5 persen; 6. Bahwa eksploitasi dan eksplorasi minyak bumi dan gas merupakan salah satu bentuk dari kegiatan perekonomian yang bertujuan untuk mewujudkan kemakmuran dan kesejahteraan rakyat Indonesia.

Hasil dari eksploitasi dan eksplorasi tersebut kemudian di terapkan dana bagi hasil minyak bumi dan gas bagi daerah penghasil, yang kemudian digunakan untuk kesejahteraan dan kemakmuran rakyat. Presentase dana bagi hasil minyak bumi dan gas pemberlakuannya berbeda antara Aceh, Papua dan daerah lain. Perbedaan mana hanya dapat terjadi apabila suatu negara menganut bentuk federasi. Hal tersebut telah tidak mencerminkan Negara Kesatuan Republik Indonesia dan kesatuan ekonomi nasional. Ketentuan dana bagi hasil minyak bumi dan gas untuk Aceh, Papua dan daerah lain (termasuk Kalimantan Timur) yang berbeda, menyebabkan telah terjadinya dualisme penerapan konstitusi dalam Negara Kesatuan Republik Indonesia.

Mahkamah Konstitusi telah memberikan pendapatnya di mana dalam Negara Kesatuan Republik Indonesia tidak mungkin berlaku dualisme pemilihan Kepala Daerah. Hal tersebut sebagiamana dalam Putusan Mahkamah Konstitusi Nomor:5/PUUV/2007 Tentang Konstitusionalitas Pasal-Pasal Undang-Undang Pemerintahan Daerah yang tidak memungkinkan perseorangan mencalonkan diri sebagai kepala daerah dan/atau wakil kepala daerah tanpa melalui Parpol atau gabungan Parpol, dalam Pertimbangan Hukum Mahkamah menyatakan pada angka (3.15.9) "Bahwa Mahkamah berpendapat, antara Pasal 56 ayat (2) Jo.Pasal 59 ayat (1) dan ayat (2) Undang-Undang Republik Indonesia Nomor 23 Tahun 2014 Pasal 67 ayat (2) Undang-Undang Pemerintahan Aceh keduanya bersumber pada dasar hukum yang sama yaitu Pasal 18 ayat (4) Undang-Undang Dasar Negara Republik Indonesia 1945. Hubungan antara pasal yang terdapat dalam Undang-Undang Pemerintahan Aceh dan yang terdapat dalam Undang-Undang Pemerintahan Daerah tersebut tidaklah dapat diposisikan sebagai hubungan antara hukum yang khusus di satu pihak, yaitu Pasal 67 ayat (2) Undang-Undang Pemerintah Aceh, dan hukum yang umum di pihak lain, yaitu Pasal 56 ayat (2) bukan termasuk dalam 
keistimewaan Pemerintahan Aceh menutut Pasal 3 Undang-Undang Republik Indonesia Nomor 44 Tahun 1999.

Oleh karena tidak dalam posisi hubungan antara hukum yang khusus dengan hukum yang umum, adanya Pasal 67 ayat (2) harus dimaknai sebagai penafsiran baru oleh pembentuk undangundang terhadap ketentuan Pasal 18 ayat (4) Undang-Undang Dasar Negara Republik Indonesia 1945. Apabila kedua ketentuan tersebut berlaku b ersama-sama tetapi untuk daerah yang berbeda maka akan menimbulkan akibat adanya dualisme dalam melaksanakan ketentuan Pasal 18 ayat (4) Undang-Undang Dasar Negara Republik Indonesia 1945. Dualisme tersebut dapat mengakibatkan ketiadaan kedudukan yang sama antara Warga Negara Indonesia yang bertempat tinggal di Provinsi Nanggroe Aceh Darusalam dan yang bertempat tinggal di wilayah provinsi Indonesia lainnya.

Warga Negara Indonesia yang bertempat tinggal di provinsi lain selain Provinsi Nanggroe Aceh Darusalamakan menikmati hak yang lebih sedikit karena tidak dapat mencalonkan diri sebagai kepala daerah dan wakil kepala daerah secara perseorangan dan oleh karenanya berarti tidak terdapatnya perlakuan yang sama di depan hukum dan pemerintahan sebagaimana dijamin oleh Pasal 28D ayat (1) dan ayat (3) Undang-Undang Dasar Negara Republik Indonesia 1945. Berdasarkan pendapat Mahkamah Konstitusi di atas dapat dipahami bahwa tidaklah mungkin memberlakukan dualisme pelaksanaan ketentuan konstitusi dalam bingkai NKRI. Hal tersebut ketika dihubungkan dengan ketentuan dana bagi hasil minyak bumi dan gas yang erat kaitannya dengan kegiatan perekonimian nasional, maka hal tersebut harus merujuk sesuai dengan Pasal 33 Undang-Undang Dasar Negara Republik Indonesia 1945.

Dengan adanya dualisme dalam pembagian dana bagi hasil minyak bumi dan gas untuk Aceh, Papua dan daerah lain (termasuk Kalimantan Timur) maka telah terjadi dualisme dalam melaksanakan konstitusi. Dalam UndangUndang Republik Indonesia Nomor 23 Tahun 2014, Undang-Undang Republik Indonesia Nomor 33 Tahun 2004 telah merujuk pada Pasal 33 UndangUndang Dasar Negara Republik Indonesia 1945 namun Undang-Undang Nomor 11 Tahun 2006 dan Undang-Undang Republik Indonesia Nomor 21 Tahun 2001 tidak merujuk pada ketentuan Pasal 33 Undang-Undang Dasar Negara Republik Indonesia 1945, seharusnya dua undang-undang tersebut merujuk pada Pasal 33.

Penyelenggaraan fungsi pemerintahan daerah akan terlaksana secara optimal apabila penyelenggaraan urusan pemerintahan diikuti dengan pemberian sumber-sumber penerimaan yang cukup kepada daerah dimana besarnya disesuaikan dan diselaraskan dengan pembagian kewenangan antara pemerintah dan daerah. Perimbangan keuangan antara pemerintah dan pemerintahan daerah mencakup pembagian keuangan antara Pemerintah dan Pemerintahan Daerah khususnya dana bagi hasil minyak bumi dan gas bumi harus dilakukan secara proporsional, demokratis, adil dan transparan dengan memperhatikan potensi, kondisi dan kebutuhan daerah. Hakekatnya pemerintah mengemban fungsi distribusi dan fungsi stabilisasi telah tidak memperhatikan fungsi alokasi yang dilakukan oleh 
Pemerintah Daerah yang lebih mengetahui kebutuhan, kondisi dan situasi masyarakatnya.

\section{Penutup}

\subsection{Kesimpulan}

Perhitungan dana bagi hasil antara pemerintah pusat dan pemerintahan daerah melalui kebijakan DAU, DAK dan dana bagi hasil menimbulkan ketimpangan antar pemerintah daerah dan pemerintah pusat karena pembagian antara DAU, DAK dan bagi hasil yang telah dirumuskan kurang berdampak terhadap daerah prioritas penghasil SDA.

\subsection{Saran}

Menurut penulis semua daerah hendaknya diberlakukan bagi hasil dengan persentase yang sama untuk sektor pendapatan atau persentase tetap, yaitu pemerintah pusat 85persen dan 15persen namun dengan catatan bahwa pemerintah pusat harus memberikan prioritas pembangunan untuk daerah penghasil SDA tersebut.

\section{DAFTAR PUSTAKA}

\section{A. Buku}

Ahmad, Yani. Hubungan Keuangan Antara Pemerintah Pusat dan Daerah di Indonesia. Jakarta: PT.Raja Grafindo Persada, 2009.

Amran, Muslimin. Aspek-Aspek Hukum Otonomi Daerah. Bandung: Alumni, 2010.

Josep, Riwu Kahu. Analisis Hubungan Pemerintah Pusat dan Daerah di Indonesia. Yogyakarta: Cetakan Ketiga, Center For Political and Government (Polgov) Fisipol UGM, 2012.

Kaufman. Tugas dan Tanggungjawab Pemerintah. Jakarta: Refika Aditama, 2011.

Setiono. Pemahaman Terhadap Metodologi Penelitian Hukum. Sukakarta: Program Studi IImu Hukum Pasca Sarjana Universitas Sebelas Maret (UNS), 2010.

Siswanto, Sunarno. Hukum Pemerintahan Daerah di Indonesia. Jakarta: Sinar Grafika, 2009.

Syaiful, Bakhri. Migas Untuk Rakyat Pergulatan Pemikiran Dalam Peradilan Mahkamah Konstitusi. Jakarta: Grafindo Khazanah IImu, 2013.

Wahyudi, Kumorotomo. Desentralisasi Fiskal, Politik dan Perubahan Kebijakan 1974-2004. Jakarta: Kencana Prenanda Group, 2008.

\section{B. Jurnal}

Bambang. "Desentralisasi Fiskal Menurut Studi Bank Dunia." Jurnal Keuangan, Oktober 2010: Volume IV, Nomor 4.

Mukhtie Fadjar Dkk. "Konstitusi Demokrasi: Sebuah Diskursus Tentang Pemilu, Otonomi Daerah dan Mahkamah Konstitusi." Jurnal Konstitusi, Januari 2011: Volume VII, Nomor 7.

Rustian Kamaluddin. "Perimbangan Keuangan Pusat dan Daerah Dalam Rangka Otonomi Daerah." Jurnal Hukum Inovatif, Juli 2009: Volume III, Nomor VI.

\section{Peraturan Perundang-Undangan}

Undang-Undang Dasar Negara Republik Indonesia Tahun 1945.

Undang-Undang Republik Indonesia Nomor 21 Tahun 2001 Tentang Otonomi Khusu Provinsi Papua.

Undang-Undang Republik Indonesia Nomor 33 Tahun 2004 Tentang Perimbangan Keuangan Pusat dan Daerah.

Undang-Undang Republik Indonesia Nomor 11 Tahun 2006 Tentang Pemerintahan Aceh.

Undang-Undang Republik Indonesia Nomor 4 Tahun 2009 Tentang Pertambangan Mineral dan Batubara 
Undang-Undang Republik Indonesia Nomor 2 Tahun 2015 Perubahan Atas Undang-Undang Republik Indonesia Nomor 23 Tahun 2014 Tentang Pemerintahan Daerah.
Peraturan Pemerintah Republik Indonesia Nomor 115 Tahun 2000 Tentang Pembagian Hasil Penerimaan Pajak Penghasilan Orang Pribadi Dalam Negari dan Pajak Penghasilan Pasal 21 Antara Pemerintah Pusan dan Pemerintah Daerah. 